\title{
'She had it coming?': An experimental study of text interpretation in a police classroom setting
}

\section{Sofia Ask}

The aim of this study is to investigate how modifications of reporting verbs, modality, style and use of quotation marks in an authentic police report can lead to different interpretations by two groups of trainee police officers. Data was collected through an experiment in a classroom setting, where police trainees discussed two versions of the same police report in focus group discussions. The trainees' statements were categorised into three themes: impression of the victim, impression of the accused, and assessment of the situation's severity. The results show that modifications such as formal or informal choice of words and the use of scare quotes proved to be influential linguistic modifications. In contrast, variation of reporting verbs and modality appeared less significant. The two versions of the text created different impressions of both the victim and the accused, and the interpretations of the severity of the situation depicted in the text varied between the two trainee groups. This highlights the importance of further study of the linguistic constructions of victims and perpetrators in police texts, in order to ensure credibility and equality before the law.

Keywords: police reports, police training, text interpretation, text modification

Sofia Ask, Department of Swedish language, Linnaeus University, 35195 Växjö, Sweden. sofia.ask@lnu.se

\section{INTRODUCTION}

A reader's perception of a text is always influenced by the author's language use and choices, and even subtle differences in the wording or syntax of a text may lead to distinct interpretations of it. When the author wishes to convince, influence, provoke or somehow trigger a response based on what has been written these choices are often conscious, but for texts that are subject to a legal requirement of maximal objectivity according to current laws and regulations, the question of the interpretative potential becomes of crucial importance.

In a police setting, oral interviews with victims, perpetrators, and witnesses must be given a written form if the documentation is to function in the judicial system. Police reports can be said to be dependent upon a shift between the oral and the written mode, in which the transformation process can cause meaning, intention and perception to be altered (Byrman 2014). Research highlights those re-contextualisation processes that oral statements undergo when they are taken out 
of their context in an interview situation and acquire a new sense in their written form in the courtroom (see Jönsson \& Linell 1996, Komter 2012, Rock 2017), which affects how the person addressed is regarded and how their testimony is understood. Transforming oral statements into written texts places considerable demands on police officers' wording of interview reports; for the account of events they must use a language that is unbiased and neutral if the report is to be legally tenable. Studying the portrayal of victims and perpetrators in police reports is thus an important research task which can provide awareness about how ostensibly objective language can generate unintended constructions of the parties involved.

In Sweden, there is an ongoing debate on the construction of 'the ideal crime victim' that has long attracted the interest of victimologists (see Wergens 2002, Smolej 2010, Jägervi 2014). It is important to expose this construction because it affects the handling of victims in the judicial system (see Bachman \& Coker 1995). A survey of the Swedish field of victimology shows that there is a lack of research into how crime victims are constructed, and the normative effects this construction might have, which points to three general areas of the study of constructions of crime victims: the victim's CREDIBILITY, LEGAL SECURITY, and EQUALITY BEFORE THE LAW (Wergens 2002:7).

In this article, I will discuss an experiment in which seemingly minor modifications of modality, choice of words, scare quotes, and reporting verbs in a police report influenced the way a group of police trainees interpreted the parties involved in a case of suspected domestic violence. The aim of this study is to investigate how linguistic constructions in police reports can affect readers' perceptions of the credibility of the parties involved, which ultimately may raise questions of legal security in the judicial system. Nevertheless, the study should be regarded as a tentative experiment which requires further study on a larger scale with more thorough investigation methods. With this article, I want to draw attention to a field that has seen little study, at least in Swedish research in forensic linguistics.

\section{LANGUAGE AND CREDIBILITY}

There are few studies of how language can construct credibility, and these studies are often in fields outside of linguistics. Hence, in the present section, I will touch upon research from other disciplines that has proven relevant for this study.

Credibility is created in different ways during verbal interaction between people. In a study of job interviews, Kerekes (2006) found that credibility is established primarily through an individual's ability to present a positive impression of themselves, and to establish functional communication between the interlocutors. However, for a victim of violence in an interview situation it can be difficult to establish such functional communication. To recount an assault or rape can 
be experienced as a 'second assault' (Holmberg 2004, Trinch 2007), or as 'revictimization' (Conley \& O'Barr 2005) since the interview situation may produce feelings of shame in the victim and (perceived or real) victim blaming on the part of the interviewer. Women who have suffered domestic violence often tend to be reluctant to take part in an investigation because they fear the process itself will question their credibility (Marklund \& Nilsson 2008).

In an interview study looking at police evaluations of victim credibility, Campbell, Menaker \& King (2015) found that judgements were primarily based on the interpretation of victims' conduct and moral characteristics. Hence, the impression interviewees create of themselves in interview situations can affect their credibility. In addition, the way victims structure their narratives around events can also play a part (see DePaulo et al. 2003). In an experiment in a courtroom setting, Voss \& van Dyke (2001) tested how factors such as cohesive narrative structures, information certainty and emotional impact influenced how the informants perceived the victim's credibility. This study shows that narrative uncertainty is the primary factor in determining whether a person is undependable, i.e. if the person is unable to coherently and convincingly recount what they were subjected to. Sperry \& Siegel (2013) conducted a similar study, in which reports from a rape trial were manipulated to study how the victim's perceived responsibility for the rape affected her credibility, and the informants' willingness to help her. That study shows that if the text implies a victim's innocence, this causes grounds for sympathy, thus increasing the victim's credibility. The opposite applies if the text suggests that the victim could be viewed as partly responsible for the rape. In this case, no sympathy is generated for the victim, and her credibility decreases (Sperry \& Siegel 2013).

The construction of crime victims in police reports has also been a topic of Swedish research. For example, Gumbel (2000) examines Swedish police reports from a linguistic perspective, focusing on markers of reported speech, pronoun usage and the shift between active and passive voice. She has examined the perspectives presented in 20 police reports on domestic violence and found that police attitudes towards men often appear distanced, whereas women are met with empathy which becomes evident in the interview texts (see Jönsson 1988, Gumbel 2000, Holmberg 2004). Gumbel states that police interviews are not just communicative tools in the legal process - they simultaneously reflect modern culture and the prevailing view of men's violence against women. Gumbel (2000:31) writes: 'assault of women becomes a social construction, surrounded by certain given attributes', arguing that victims are often constructed based on attributes linked to class and ethnicity, as well as to social factors such as unemployment, mental illness, substance abuse, etc.

There are only few examples of language use affecting the outcome of a Swedish court case. I will elaborate on two specific cases. In the first case, the choice of preposition proved critical, since the question the court had to consider was whether there is a difference between spitting AT and spitting ON a police officer (Widlund 
2013). A young man was charged with outrageous conduct toward a public servant because he spat at a policeman while being arrested. He was acquitted by the district court on the grounds that it was unclear whether the spit actually hit the policeman since, according to the written report, he had 'spat at' (spottat mot) and not 'spat on' (spottat på) the policeman. There was an appeal against the judgement, and in the court of appeal the description of the offence was adjusted so that it also incorporated the aim of the spitting being 'to obstruct the police in the exercise of authority, and this constituted a nuisance' (Widlund 2013). The young man was found guilty of having spat at the policeman in order to prevent him from doing his duty, but he was not fined for the deed.

My second example is an investigation into a case of assault where mentions of a bruise as big as a 5-krona coin was decisive to the outcome of the trial. The case involved a young woman (referred to as 'Mary Bloom') who submitted a complaint to the police stating she had been assaulted by a former boyfriend ('John Brown'). John denied the accusation. In the excerpts from the police reports from the investigation, presented in (1)-(3) below, all mentions of the bruise are underlined. The first mention of the bruise is in the police report of the victim's complaint, under the headings 'The crime' and 'Injuries' (excerpts from Swedish police reports are given in the original form, followed by an English translation; for ease of presentation, subsequent in-text quotations of the reports are given in English).

\section{(1) THE CRIME}

John Brown är skäligen misstänkt för misshandel genom att han knuffat omkull Mary och därefter sparkat Mary på låret. Mary kände smärta av sparken och ett blåmärke uppstod.

'John Brown is suspected on reasonable grounds of assault by having pushed Mary over and then kicked Mary on the thigh. Mary felt pain from the kick and a bruise developed.'

\section{INJURIES}

Mary fick ett blåmärke på låret, en 5-kronas storlek. Mary uppsökte aldrig sjukhus för att dokumentera sina skador.

'Mary developed a bruise on the thigh, the size of a 5-krona coin. Mary never visited the hospital to document her injuries.'

The bruise thus occurs for the first time in the victim's complaint but in different ways under the two headings. In the description of the crime it is simply mentioned as a bruise, whereas in the description of the injury this is reinforced with the phrase 'the size of a 5-krona coin'. In the following extract, from an interview with Mary, the bruise is described in more detail: 
(2) När grälet återuppstått sparkade John Mary på låret. Mary kände smärta av sparken och fick ett blåmärke, blåmärket var stort som en 5-krona i omkrets.

'When the argument resumed John kicked Mary on the thigh. Mary felt pain from the kick and developed a bruise, the bruise's circumference was as big as a 5-krona coin.'

In the interview text above, the description is expanded to clarify that the circumference of the bruise is 'as big as a 5-krona coin'. There is no reporting verb here to show that these are Mary's words nor are there any quotation marks that could attribute the phrase to Mary.

In an interview with a witness to the event, namely Mary's sister, Julia, the description of the size of the bruise returns:

(3) Mary visade Julia blåmärket, det var stort som en femkrona. Kanske lite större. 'Mary showed Julia the bruise, it was as big as a five-krona. Perhaps a bit bigger.'

In the phrase 'perhaps a bit bigger' the size of the bruise has also increased in the sister's statement, but again with no indication of who said it.

John denies assaulting Mary, and when the case is brought to court, the charge is dismissed and he is acquitted. The district court attaches great importance to the description of the size of the bruise, either being as big as 'the size of a 5-krona coin' (in the excerpt in (1) above) and 'as big as a five-krona' (in the excerpt in (3)) and writes the following in the judgement:

(4) Tingsrätten finner Mary Blooms ganska detaljerade uppgifter i förening med systerns vittnesmål talar för att John Brown gjort sig skyldig till det som påståtts. Det framstår emellertid som anmärkningsvärt att båda systrarna beskrivit blåmärkets storlek på samma sätt. Då det inte kan bortses från möjligheten att de som bor tillsammans inför rättegången kommit överens om vad ska säga, bör Mary Blooms vittnesmål bedömas med försiktighet.

'The district court finds that Mary Bloom's rather detailed information is consistent with her sister's witness statement, stating that John Brown is guilty of what has been claimed. It seems remarkable, however, that both sisters describe the size of the bruise in the same way. Since one cannot ignore the possibility that, as they lived together before the trial, they agreed on what to say, Mary Bloom's testimony should be assessed with caution.'

Because the sisters used the same phrase, stort som en femkrona 'the size of a five-krona coin', the district court deems it likely that they agreed on a story which included that precise wording. The problem is that the origin and use of that particular phrase does not have any clear owner. The lack of explicit reporting constructions in these interview reports means that there are no clues to the origin or ownership of 
the phrase, which is problematic. From a linguistic perspective, it is compelling that a short, seemingly innocent phrase about the size of a bruise has moved through the judicial system and become of crucial importance in court (see Rock 2013).

\section{METHOD}

As part of a field study of police training at Linnaeus University in Växjö, I conducted an experiment with 30 trainee police officers, 26 male, four female. The gender aspect was ignored due to the fact that the group of trainees was small, and hence the collected data would not have given any substantial findings with regard to gender. The officers were nearing the end of their training and at the time of the experiment they had worked on report writing about domestic violence. In this specific experiment, I wanted to investigate whether linguistic modifications at different levels in a report from an interview with a victim could influence how future police officers assess the situation and the individuals in a case of suspected abuse of a woman. The text material used in this study comes from the research material from the project Texts with Importance at Linnaeus University (see Ask \& Byrman 2010), which examines how professional education programmes prepare students for writing in their future occupation (see Russell 1997; Parks 2001; Schneider \& Andre 2005; Ask 2010, 2014). As part of the project, one of the research interests was trainee police officers' approach to writing in the line of duty and how they receive training to write the texts required by the profession.

Since previous research has shown that victim blaming affects the credibility of female witnesses (see above and also Conley \& O'Barr 2005, Trinch 2007), I extracted an interview with a female abuse victim from an authentic police report. The text from the interview with the woman was presented as a case where the trainee police officers were asked to imagine a situation common to their profession: They are to take over an inquiry in an on-going investigation and therefore need to read through previous interviews to familiarise themselves with the case. The trainees were also given the following case background: Someone phones the police to say that it sounds like there is a dispute in the neighbouring flat. There is a couple living there whom I have chosen to call Tom and Bridget, who no longer work and are known to have problems with substance abuse. In order for the focus group interviews to provide answers to my questions, I designed three thematic focus points to promote discussion: perceptions of the victim, perceptions of the accused, and assessment of the severity of the situation. The following written instructions were then distributed to the trainees:

You and a colleague are going to interview a victim in an assault case, so you read up on the investigation report. Read the text and then discuss the following questions: 
- What impression of Bridget is conveyed in the text?

- What impression of Tom is conveyed in the text?

- Is this a serious situation?

By modifying modality, style, quotation marks, and reporting verbs, I thus created two versions of the original interview text, described in further detail in Section 3.1 below. The trainee police officers who participated in the experiment were divided into two groups and were given the two versions of the document that were designed to resemble the official reports they were familiar with. They were unaware that they had been given different versions of the text, and discussed their versions of the Bridget interview in two separate rooms for about 30 minutes. The groups reconvened, and I initiated the focus group discussions in which the trainees were encouraged to speak freely and share their interpretation of the case of Tom and Bridget based on the three thematic questions. During this process, I collected their interpretations and documented vital points through notes on the whiteboard, and through annotations in a field study protocol (see Greenbaum 1998).

As the tentative conclusions from the focus group discussion build upon a consensus reached on the different questions, this presents a weakness in the design of the study. Consequently, I cannot provide quantitative data of the number of trainees who assumed one stance or the other, though there is qualitative data collected from the trainees' statements in the discussions. That considered, the results should be viewed as preliminary. Nevertheless, this study is an innovative attempt to review whether it is possible to ascertain if and how manipulated police reports can influence readers' notions of credibility of the parties involved. I intend this study to be a first step towards a more comprehensive and more stringently designed investigation focusing on the significance of language in the interpretation of police reports.

\subsection{Modifications of the text}

The modifications in the two versions of the interview text did not alter the facts presented in any way, nor do the resulting texts differ from typical modes of expression in Swedish police writing (see Ask 2012). In creating the two versions (henceforth Version A and Version B), I ensured that the modifications would not be too obvious and that the stylistic level of the texts would remain the same so that it would appear plausible to the trainee police officers. I used a total of four categories of modifications: MODALITY, STYLE, SCARE QUOTES, and REPORTING VERBS.

\subsubsection{Modality}

Modality is a linguistic tool that gives the potential to modify an indicative clause (e.g. I am going home now) in order to express, for instance, what is reasonable (I should 
go home now), what is necessary (I must go home now), or what is desirable (I want to go home now). In Swedish, this is normally done using modal auxiliaries such as kan 'can', bör 'should', brukar 'usually (do)', måste 'must', skulle 'should', and vilja 'want' (see Holmberg \& Karlsson 2006), but also with the aid of sentence adverbials such as kanske 'perhaps', säkert 'certainly', troligen 'probably', nog 'surely'. Modality can thus be used to express greater or lesser certainty in a statement, but also to emphasise the participants' mutual power relations (see Pappinen 2010). In the manipulated texts, modality is varied by the insertion or deletion of the following modal verbs: kunna 'be able to', vilja 'want to', få 'be allowed to', and bruka 'usually (do)'.

\subsubsection{Style}

The stylistic value of words depends on factors such as conventions, linguistic tolerance, and personal preferences based on where one grew up and the surrounding context, culture and environment (Hellspong 2004). The evaluation and interpretation of different stylistic levels is thus affected by acquired perceptions of what is beautiful or ugly, acceptable or unacceptable. However, colloquial styles in police reports risk trivialising what is being described, and this may in turn affect the reader's assessment of the individuals involved. For that reason, synonyms of varying stylistic value were incorporated in the texts used in the experiment, creating a shift between formal and informal style in the different versions, for example by using the informal prata 'talk' instead of the more formal samtala 'converse', possibly eliciting different assumptions about the speaker in question.

\subsubsection{Scare quotes}

Scare quotes are quotation marks that offer writers a way to distance themselves from a particular content, for example in the case of strong words uttered by other participants, such as Det luktade "skit" $i$ lägenheten "It smelled like "shit" in the flat'. According to guidelines published by The National Police Board in Sweden, quotation marks should be used for verbatim quotations only (Riktlinjer för skrivande inom Polisen 2013). Nevertheless, research shows that quotation marks are commonly used around colloquial expressions or slang, as a means for the writer to distance him/herself from what is being reported (see Jönsson 1988, Gumbel 2000, Pappinen 2010). But scare quotes can also be a tool for irony or sarcasm, as in Hon var full och satt på parkbänken och drack "saft" 'She was drunk and sat on the park bench drinking "juice". This type of scare quotes is sometimes called 'sneer quotes' (Jacobs 2003, Nacey 2012), meaning that the reader is supposed to detect and understand the irony in the statement. Sneer quotes are used in Version A to mark a 'male acquaintance'. 


\subsubsection{Reporting verbs}

Retelling and summarising a course of events is a common feature of police reports. Attention to the use of reporting verbs is particularly important when studying police texts (Byrman 2014) since they can affect the reader's perception of the writer's attitude to what is described and thus also ultimately contribute to the assessment of the interviewed person's credibility (see Holt 1996, Byrman 2014). In Swedish, reporting verbs such as påstå 'claim' can signal doubts about the suspect's statements, whereas säga 'say' or berätta 'tell' signal a neutral, objective attitude to what is said in the text. The most common reporting verbs in Swedish police texts, according to Gumbel (2000), are uppge 'state', berätta 'tell', säga 'say', tro 'believe', and förklara 'explain'. Stylistically, reporting verbs like uppge, påstå, and hävda (all meaning 'claim') can mark a clear distance due to their formal register (Pappinen 2010) and can therefore affect the reader's perception of what is being rendered.

Sometimes, rendering someone else's speech is not indicated in the text, and with the absence of reporting verbs comes an absence of their accompanying grammatical subjects, making it impossible to determine who uttered the words. The possibility of refraining from any reporting markers and simply retelling the event as a fact, for example, Eva fick två hårda slag $i$ buken 'Eva received two heavy blows to the abdomen', forces the reader to use context to connect the statement to the right person, which involves a risk that the statement is regarded as a fact, rather than as an account given by an involved party.

\subsection{The text in three versions}

The extract from the original interview with Bridget is as follows (only names have been changed):

(5) Bridget berättar att hon vid tillfället som misshandeln skedde, satt i köket och pratade i telefonen med en manlig bekant. När hon lagt på luren kommer hennes man Tom in i köket och börjar slå henne. Bridget säger att hon fick motta ett knytnävsslag på munnen, sedan 2-3 stycken knytnävsslag $i$ huvudet och sedan tog Tom tag $i$ hennes vänstra handled och slog den mot elementet. Under tiden som Tom slår Bridget berättar hon att hon ringde polisen och då försökte Tom ta telefonen ifrån henne. När det inte gick fortsatte han att slå.

Bridget menar att han dricker upp nästan alla pengarna, att han brukar börja dricka när förtidspensionen kommer och sedan i en till två veckors tid, och i och med att han är så kontrollerande och aggressiv så vågar hon inte säga emot. Hon säger vidare att hon inte får umgås med andra människor, och när hon väl ska gå ut på krogen brukar Tom kalla henne för otidigheter såsom "jävla hora", vilket resulterar $i$ att Bridget numera inte går ut alls. 
'Bridget tells how at the time of the assault, she was sitting in the kitchen and talking to a male acquaintance on the phone. Once she hung up, her husband Tom came into the kitchen and began hitting her. Bridget says that she received a punch to the mouth, followed by 2-3 punches to the head. Tom then took hold of her left wrist and hit it against the radiator. While Tom was hitting Bridget, she tells how she called the police and at this point Tom tried to take the telephone away from her. When this was not possible, he continued to hit her.

Bridget states that he drinks away almost all the money. He usually starts drinking when he receives his pension and then drinks for the next one or two weeks. Because he is so controlling and aggressive, she does not dare raise objections. She further says that she is not allowed to socialise with other people, and when she would like to go out to the pub, Tom calls her abusive names such as "fucking whore", and so Bridget no longer goes out at all.'

By using the modifications of the kind described above, I created two VERSIONS of the same interview text: one where Bridget can be doubted (Version A) and one where she seems credible (Version B). To facilitate reading, I have divided the text into five UNITS in chronological order and present the different versions below in each unit. The modifications are underlined.

\subsubsection{Unit 1: Modality and sneer quotes}

In the original version in this first unit, the reporting verb berätta 'tell' is used to indicate that it is the woman's own description of the event that is rendered, and the tone is neutral and objective. When the original text is modified in Versions A and B, the changes concern modality, choice of words, and the use of sneer quotes.

Version A

Bridget berättar att hon vid tillfället som misshandeln ska ha ägt rum, satt $i$ köket och pratade i telefonen med en "manlig bekant". När hon lagt på luren kommer hennes man Tom in i köket och börjar slå henne.

'Bridget tells how at the time the assault is to have taken place, she was sitting in the kitchen chatting [prata] to a "male acquaintance" on the phone. When she hung up, her husband Tom came into the kitchen and started hitting her.'

Version B

Bridget berättar att hon vid tillfället som misshandeln skedde, satt i köket och samtalade $i$ telefonen med en manlig bekant. När hon lagt på luren kommer hennes man Tom in i köket och börjar slå henne. 
'Bridget tells how at the time of the assault, she was sitting in the kitchen talking [samtala] to a male acquaintance on the phone. When she hung up, her husband Tom came into the kitchen and began hitting her.'

In Unit 1 there are three modifications: two in Version A and one in Version B. The first involves modality, and in Version A a phrase is added ('the time when the assault is to have taken place'). More specifically, the phrase 'is to have taken place' suggests that the assault might not have happened and is just something that Bridget claims. In Version B, the modality is unchanged in relation to the original text and notes a fact in the phrase 'at the time of the assault'. The other modification is a matter of the choice of words. By changing the colloquial prata 'talk' of the original text to the more formal samtala 'converse' in Version B, Bridget is portrayed as more austere and composed. Finally, sneer quotes were put around manlig bekant 'male acquaintance' in Version A to suggest a tone of irony that can make Bridget seem blameworthy.

\subsubsection{Unit 2: Reporting verbs}

In Unit 2, the writer in the original version varies between berätta 'tell' and säga 'say' when quoting what was said, but is still objective in continuing to allow the woman's narrative to be heard.

Version A

Bridget påstår att hon fick motta ett knytnävsslag på munnen, sedan 2-3 stycken knytnävsslag $i$ huvudet och sedan tog Tom tag $i$ hennes vänstra handled och slog den mot elementet.

'Bridget claims that she received a punch to the mouth, followed by $2-3$ punches to the head and then Tom grabbed her left wrist and hit it against the radiator.'

Version B

Bridget säger att hon fick motta ett knytnävsslag på munnen, sedan 2-3 stycken knytnävsslag $i$ huvudet och sedan tog Tom tag $i$ hennes vänstra handled och slog den mot elementet.

'Bridget says that she received a punch to the mouth, then 2-3 punches to the head and then Tom grabbed her left wrist and hit it against the radiator.'

Here the reporting has been changed in two ways: in Version A, the verb påstå 'claim' is used and in Version B the reporting verb is deleted (indicated by crossed-out words). The use of the verb påstå in Version A suggests that Bridget is not credible, while the removal of the reporting verb in Version B portrays it as a fact that she really was punched on the mouth. Both of these modifications are subtle in that they can 
guide the reader's interpretation; to 'claim' is less objective than to 'say' something. The deletion of the reporting phrase 'says that' means that that the assault alleged by Bridget in her statement is no longer an allegation but can now be interpreted as an established fact.

\subsubsection{Unit 3: Reporting verb}

In Unit 3, I chose to make just one modification, namely, to vary the use of reporting verbs in Version A in order to continue suggesting to the reader that there is reason to be sceptical of Bridget's testimony.

Version A

Under tiden som Tom slår Bridget påstår hon att hon ringde polisen och då försökte Tom ta telefonen ifrån henne. När det inte gick fortsatte han att slå.

'While Tom was hitting Bridget she claims she called the police and at this point Tom tried to take the telephone away from her. When this was not possible, he continued to hit her.'

Version B

Under tiden som Tom slår Bridget berättar hon att hon ringde polisen och då försökte Tom ta telefonen ifrån henne. När det inte gick fortsatte han att slå.

'While Tom was hitting Bridget she says she called the police and at this point Tom tried to take the telephone away from her. When this was not possible, he continued to hit her.'

The police writer continues to let Bridget tell her story in the original version, using the neutral reporting verb berätta 'tell'. This is retained in Version B, giving Bridget a voice and a place for her own account of what happened. However, in Version A, the verb påstå 'claim' is used again, which possibly reinforces doubts by the fact that it is repeated, thus increasing possible doubts about the truth of Bridget's statement.

\subsubsection{Unit 4: Reporting verb, modality, choice of words}

In the original version, the writer here uses the reporting verb mena 'mean', which is synonymous with the Swedish verbs tycka or anse, meaning 'think, consider, be of the opinion', verbs to do with viewpoints rather than facts.

Version A

Bridget påstår att han dricker upp nästan alla pengarna, att han brukar börja dricka när förtidspensionen kommer och sedan i en till två veckors tid, och i och 
med att han ibland kan vara så kontrollerande och arg så vågar hon inte säga emot.

'Bridget claims that he drinks away almost all the money. He usually starts drinking when he receives his pension and then drinks for the next one or two weeks. Because he sometimes can be so controlling and angry, she does not dare raise objections.'

Version B

Bridget berättar att han dricker upp nästan alla pengarna, att han brukar börja dricka när förtidspensionen kommer och sedan i en till två veckors tid, och $i$ och med att han är så kontrollerande och aggressiv så vågar hon inte säga emot.

'Bridget says that he drinks away almost all the money. He usually starts drinking when he receives his pension and then drinks for the next one or two weeks. Because he is so controlling and aggressive, she does not dare raise objections.'

In Unit 4, I continue to use the reporting verb påstå 'claim' in Version A to plant doubt about Bridget's credibility for a third time. In Version B, however, she continues to 'tell' (berätta) her story, which increases her chances of being perceived as credible. The original version contains the phrase 'he is so controlling and aggressive', which is a statement of fact. Two important modifications have been made in Version A. First, a verb phrase, 'sometimes can be' is added so that Tom is not described as being constantly aggressive, and secondly, 'aggressive' in the original version has been toned down to an arguably milder 'angry'.

\subsubsection{Unit 5: Reporting verb, choice of words, modality}

In the last passage of the text, there are not only modifications in the reporting, but also in the choice of words and modality. The original version is still objective as regards the tone and the choice of reporting verb (säga 'say'), and continues to render the woman's account without invoking either doubt or sympathy.

Version A

Hon hävdar vidare att hon inte får umgås med andra människor, och när hon väl ska gå ut på krogen händer det att Tom kallar henne för otidigheter som "jävla hora", vilket resulterar $i$ att Bridget numera inte vill gå ut alls.

'She further claims that she is not allowed to socialise with other people, and when she would like to go out to the pub, Tom may on occasion call her 
abusive names such as a "fucking whore", and so Bridget no longer goes out at all.'

\section{Version B}

Hon säger vidare att hon inte får umgås med andra människor, och när hon väl ska gå ut och roa sig brukar Tom kalla henne för otidigheter såsom "jävla hora", vilket resulterar $i$ att Bridget numera inte går ut alls.

'She further says that she is not allowed to socialise with other people, and when she does go out and enjoy herself, Tom calls her abusive names such as "fucking whore", and so Bridget no longer wants to go out at all.'

In this unit, the reporting verb hävda 'claim' is used instead of påstå 'claim'. The verb hävda is synonymous with påstå 'claim' in Swedish, but it has a more formal tone. The word otidigheter 'abusive names' for Tom's remarks in the original version is deleted in Version A so that his language will not be labelled as reprehensible. However, it is kept in Version B thus reinforcing the verbal abuse by labelling the disparaging language that Bridget reports to the police.

Version A modifies the phrase 'Tom calls her a fucking whore' with the temporal adverbial 'on occasion', implying that it does not happen habitually. If something happens on occasion it is perhaps less serious than if someone habitually or always insults their partner with abusive language. On a stylistic level the phrase 'go out to the pub' is somewhat colloquial in Swedish, and is hence given a more serious tone in 'go out and enjoy herself', which invites the interpretation that Bridget is a well-behaved person. Finally, the phrase stating that Bridget now 'no longer goes out at all' (original version and Version A) has the added words 'no longer wants to go out at all' in Version B. This means that Bridget CAN go out, but that she CHOOSES not to do so, reducing the extent to which Tom is responsible for preventing Bridget from going out.

\section{RESULT: ABUSED OR NOT?}

\subsection{Group A: 'She had it coming'}

In response to the first discussion question, 'What impression of Bridget does the text convey?', Group A chose not to discuss Bridget's personality, but quickly reached the opinion that her actions are reproachable. In particular, the phrases 'go out to the pub' and 'male acquaintance' appear to have influenced the evaluation, as the trainee police officers returned to these particular remarks several times during the discussion. Both of these points were suspect in the group's opinion, since going to the pub, as one trainee highlights, 'suggests drunkenness and potential 
infidelity', which is then reinforced by the fact that Bridget has 'male acquaintances' (all statements made by the police trainees in this section were translated into English by the present author). The trainee who made this comment used his hands to gesture sneer quotes, wishing to emphasise the irony in the phrase and insinuate that Bridget is more than friends with these men and therefore she cannot be trusted. The linguistic modifications that primarily appear to influence the trainees' perception of Bridget relate to how activities (going to the pub) and relationships (having male acquaintances) are described through choice of words, register and irony markers such as sneer quotes.

When the trainees in Group A were asked to describe Tom and their impressions of him, they began by questioning whether or not there had been abuse in the flat to begin with. One trainee in Group A assessed the situation as 'This is really not wife beating, but jealousy', effectively exonerating Tom from guilt because he was jealous. Another trainee was more nuanced, and said: 'Tom is a little unpredictable, but it's not that serious'. This palliating attitude suggests that jealous men can be excused for their actions if the woman's behaviour is questionable, and also downplays the crime via the phrase 'not that serious'. Moreover, there was a group consensus that Tom 'does not trust his wife' based on the description of Bridget's behaviour and relationships as portrayed in the text they had just read.

Group A was not convinced of the severity of Bridget's situation and toned down the seriousness of the circumstances. This was evident in comments such as 'There has been physical violence, but not very serious'. One trainee stated that 'Bridget exaggerates the situation', and another added that 'She hasn't been too beaten up and she had it coming'. The couple's alcohol problems are also noted by the group, with one conclusion being that they 'are both involved in a bad relationship'. This assigns responsibility for the abuse to both Bridget and Tom. Therefore, the overall Group A assessment was that the situation was not particularly serious and that Bridget partly had herself to blame.

\subsection{Group B: 'This is a serious incident'}

The group that had read Version B described Bridget's personality rather than her behaviour and actions: 'She seems to be a calm and submissive person, in my opinion', said one of the trainees. The issue of guilt was important also to this group, and they were in agreement that Bridget could not be held responsible for having been assaulted, which was made particularly clear by the statement: 'In this situation, she is innocent - because there is no excuse for abuse'. No trainee in Group B voiced anything to say that they consider Bridget even partly responsible for the destructive nature of the couple's relationship.

The trainees in Group B also commented on Bridget's friendships, but focused on how she was unable to develop them. The statement 'She has acquaintances, but she 
does not go out to meet them' contrasts with the interpretation from Group A, who believed that Bridget's relationships with others were questionable, and therefore made her unreliable. The stylistic level of the statements in Group B also tended towards a more formal tone, which can be an effect of the modifications in Version B colouring their choice of words.

Tom was described as an 'aggressive', 'controlling', 'unpredictable' and 'violent' alcoholic by Group B. One trainee stated 'I think he is aggressive, and obviously controlling. I mean, she won't go out!', which gives a clear example of how the trainees viewed Tom. General conclusions about Tom were also reached, for example 'Being an alcoholic, he is probably prone to violence', which suggests a presumption that all people with alcohol problems abuse their partners. One trainee believed that Tom is the reason for Bridget's submissive nature: 'Tom, I think, is unpredictable and Bridget is submissive because of that'.

This group unanimously assessed Bridget's situation as serious, which was expressed through statements such as 'This is a serious incident' and 'Bridget has been beaten'. It thus seems as if this group was in agreement about the severity of Bridget's situation, and in their line of duty as police officers they would feel justified in intervening.

\subsection{Conclusion}

It appears that the stylistic modifications of the texts have made the strongest impact, particularly those that address how Bridget's relationships are described - the difference between 'male friend' and 'male acquaintance' affects the interpretation in both groups. In contrast, other modifications, such as reporting verbs and modality, do not appear to have had any influence beyond maybe implicitly, as the trainees' statements do not give any indication that the modifications to the reporting verbs or modality have affected their evaluations. One explanation may be due to the subtle functions of these linguistic tools, which perhaps go unnoticed when the content is the focus of the reading. The trainee police officers most probably focus on WHAT the text says rather than HOW it is expressed.

Both modified versions of the interview texts appear to create an understanding that Tom is unpredictable, as this specific description arises in statements from both groups. There is only one passage in the two different versions that could explain this interpretation: 'When she hung up, her husband Tom came into the kitchen and started hitting her' (original version). No modifications were made to this particular sentence, suggesting that both groups unanimously believe that Tom's sudden attack in the original narrative was unpredictable. Further modifications to the text as a whole no doubt contribute to determining how this unpredictability is evaluated; either as negligible (Group A) or serious (Group B). 
The trainees' evaluation of the severity of the situation is critical, as it could potentially affect their subsequent processing of cases such as that of Bridget and Tom's. The impression an interview text creates can potentially influence the direct treatment of those involved in further interviews, and in the continued contact with the police - both the woman and the man may be pre-determined as victim and perpetrator, respectively. Both trainee groups seem to agree that there has been violence in Tom and Bridget's home, but there were different perceptions of the severity of the violence and how the accountability for it should be distributed between the parties. Group A made the overall assessment that the situation was not particularly serious and that Bridget had herself to blame, whereas Group B found the situation serious and focused on Bridget's suffering physical abuse and violation of her integrity. Thus, Version A portrays Bridget as a less credible victim, and Version $\mathrm{B}$ gives rise to interpretations that judge Tom in advance as a perpetrator.

The changes to the language in the original text thus proved to be significant enough to give rise to two different interpretations of the situation, and the combined effect of the modifications led the trainee police officers to make different assessments of the credibility of the parties involved. This experiment shows on a small scale how language can lead and mislead, and by extension this means that people's legal security can be jeopardised by the linguistic choices in police interview texts and other legal documents.

\section{LANGUAGE AND CREDIBILITY}

While police reports strive for objectivity, even minute differences in wording can affect the way they are read and potentially whether a prosecution is initiated and how the final judgement falls out, as seen both in the examples in the introduction and in the experiment that I have described here. Taken separately, particular words and phrases may seem harmless, but the combined effect can be decisive. Therefore, it should be noted that it is likely not the individual changes in this experiment that prompted the different interpretations, but rather the accumulated impact of the manipulations.

The evaluation of the interviewees' credibility is linked to how they are presented in speech and writing. Often, these interpretations of the victim's behaviour and moral character are conclusive - as evident from the studies by Sperry \& Siegel (2013) and Campbell, Menaker \& King (2015). My study also shows that perceptions of a victim's behaviour and character influence the interpretations of the severity of the situation. The trainees who read Version A, in which Bridget appears of dubious character, mainly dwell upon questions of her morality, and conclude that she is unreliable and at least partly responsible for the violence she is subjected to. In contrast, if victims' morals appear to be beyond reproach, they tend to be met with 
empathy and viewed as credible (see Sperry \& Siegel 2013). This was evident in Group B, who read the version in which Bridget is portrayed as a calm, innocent, submissive woman. Moreover, the portrayal of the alleged perpetrator in the interview texts can have a similar impact. Gumbel (2000) shows that men accused of violent crimes against women are met with distance in their contact with the police, which can contribute to them being construed as perpetrators. In my study, the trainees in Group B believe that Tom is aggressive, controlling and unpredictable, which must be ascribed to the description of him in the text. In the continued investigation and legal proceedings for which the texts form the basis of potential prosecution, Tom may find it hard to distance himself from the construction of him as a perpetrator, which raises questions of legal security and equality before the law.

The conclusion I draw is that the choice of formal and informal vocabulary and sneer quotes are potentially influential modifications, since they recur in the trainees' assessments and seem to be a reason for their scepticism about Bridget's credibility. Reporting verbs and modality, however, seem to play a smaller role in the interpretation of the text as a whole. Even if the reporting verbs påstå 'claim' and hävda 'claim' have inherent seeds of doubt, the present study does not suggest an influence of the choice of reporting verbs on the trainees' interpretation. To confirm these conclusions, however, studies are needed of the strength, quantity, and mutual influence of different modifications on the reader. The result of the present experiment hints at the importance of research which can create an awareness of the linguistic features that may steer the reader in directions not envisaged or intended by the writer. This is particularly important for all those who write official texts that could have consequences on people's lives - but also personally for victims, perpetrators, and witnesses whose stories are retold in written text and whose credibility is thus at stake. When police officers render the crime victim's statements and do not make efforts to preserve their credibility in a neutral way, victims' legal security can be threatened (see Wergens 2002).

The results of this study ultimately suggest that linguistic choices in official texts can have consequences for the construction of both alleged victims and perpetrators - which was highly polarised in the interpretations by the two groups of trainees: Bridget is in danger or Bridget has herself to blame. A similar polarisation occurs in the construction of Tom as the perpetrator, who is either a violent abuser or a man living in a destructive relationship where both parties are to blame for the situation. This indicates the importance of further studying linguistic constructions of victim and perpetrator in interview texts in order to maintain their credibility and equality before the law.

For trainee police officers who have not yet started working in police practice, writing fully neutral reports poses a demanding challenge. It is perhaps unreasonable to assume that trainees in an educational context should be able to appropriate functional professional writing (see Russell 1997; Parks 2001; Schneider \& Andre 
2005; Ask 2010, 2014), but there must always be an effort to prepare police trainees for report writing as much as possible, by giving them knowledge and linguistic tools for a future exercise of authority that ensures legal security for all parties involved.

\section{ACKNOWLEDGEMENTS}

This paper is based on research conducted as a part of my collaboration with the Police Academy at Linnaeus University, Växjö, Sweden. I would like to thank the anonymous participating police trainees, but especially officers Per Esbjörnsson and Carina Hansson, who made the experiment possible by letting me into their classroom. I also would like to thank the $N J L$ reviewers for their constructive comments and useful insights.

\section{REFERENCES}

Ask, Sofia. 2010. "Skola är en sak och myndigheten är något annat": Skrivundervisning på svensk polisutbildning ['Education is one thing and police work is something else': Writing instruction in Swedish police training]. In Lars Erik Lauritz \& Mehti Ghazinour (eds.), Nordisk polisforskning: Konferensskrift från den tredje nordiska polisforskningskonferensen Umeå 2010 [Nordic Police Research: Conference Proceedings from the Third Nordic Conference for Police research, Umeå 2010], 15-28. Umeå: Umeå universitet.

Ask, Sofia. 2012. Skrivande polis [Police writing]. Lund: Studentlitteratur.

Ask, Sofia. 2014. Authoritative language in police training: Style in police students' memoranda. In de Guzman et al. (eds.), 193-203.

Ask, Sofia \& Gunilla Byrman. 2010.”Så slog han Maria med ett okänt antal knytnävslag i ansiktet": Reliefanalys av polisstudenters och polisers skrivande ['Then he repediately hit Maria in the face': Content analysis of police trainees and working police officers' writing]. In Jon Smidt, Ingvild Folkvord \& Arne Johannes Aasen (eds.), Rammer for skriving: Om skriveutvikling $i$ skole og yrkesliv [Frames for writing: On writing development in education and work life], 125-141. Trondheim: Tapir akademisk forlag.

Bachman, Ronet \& Ann Coker. 1995. Police involvement in domestic violence: The interactive effects of victimization, offender history, violence, and race. Violence and Victims 10(2), 91-106.

Byrman, Gunilla. 2014. Police writing techniques in reported interviews. In de Guzman et al. (eds.), 247-262.

Campbell, Bradley A., Tasha A. Menaker \& William R. King. 2015. The determination of victim credibility by adult and juvenile sexual assault investigators. Journal of Criminal Justice 43(1), 29-39.

Conley, John M. \& William M. O’Barr. 2005. Just Words: Law, Language and Power, 2nd edn. Chicago, IL: University of Chicago Press.

de Guzman, Melchor C., Aiedeo Mintie Das \& Dilip K. Das (eds.). 2014. The Evolution of Policing: Worldwide Innovations and Insights. Boca Raton, FL: Taylor \& Francis.

DePaulo, Bella M., James J. Lindsay, Brian E. Malone, Laura Muhlenbruck, Kelly Charlton \& Harris Cooper. 2003. Cues to deception. Psychological Bulletin 129(1), 74-118. 
Greenbaum, Thomas L. 1998. The Handbook for Focus Group Research, 2nd edn. Thousand Oaks, CA: SAGE.

Gumbel, Ingatora. 2000. Hörd angående misshandel: Polisens protokoll vid förhör med misshandlade kvinnor och misstänkta män [Questioned regarding assault: Police reports of interviews with battered women and male suspects] (TeFa: text- och fackspråksforskning 38). Stockholm: Stockholm University.

Hellspong, Lennart. 2004. Konsten att tala: Handbok i praktisk retorik [The art of speaking: Handbook in practical rhetoric]. Lund: Studentlitteratur.

Holmberg, Ulf. 2004. Police Interviews with Victims and Suspects of Violent and Sexual Crimes: Interviewees' Experiences and Interview Outcomes. Stockholm: Stockholm University.

Holmberg, Per \& Anna-Malin Karlsson. 2006. Grammatik med betydelse: en introduktion till funktionell grammatik [Grammar with meaning: An introduction to functional grammar]. Uppsala: Hallgren \& Fallgren.

Holt, Elizabeth. 1996. Reporting on talk: The use of direct reported speech in conversation. Research on Language and Social Interaction 29(3), 219-245.

Jacobs, Alan. 2003. The war in quotes: Journalists who don't like the war - and like thinking even less - have a little trick they use to tell us how they really feel. Weekly Standard, 14 April 2003. http://www.weeklystandard.com/Content/Public/Articles (accessed 15 September 2017).

Jägervi, Lotta. 2014. Who wants to be an ideal victim? A narrative analysis of crime victims' self-presentation. Journal of Scandinavian Studies in Criminology and Crime Prevention 15(1), 1-19.

Jönsson, Linda. 1988. On Being Heard in Court Trials and Police Interrogations: A Study of Discourse in Two Institutional Contexts (Linköping Studies in Arts and Science 25). Linköping: Linköpings universitet.

Jönsson, Linda \& Per Linell. 1996. Misstroendesekvenser i polisförhör [Sequences of mistrust in police interviews]. In Mats Thelander (ed.), Samspel och variation [Interplay and variation], 199-208. Uppsala: Uppsala universitet, Institutionen för nordiska språk.

Kerekes, Julie, A. 2006. Winning an interviewers trust in a gatekeeping encounter. Language in Society 35(1), 27-57.

Komter, Martha. 2012. The career of a suspect's statement: Talk, text, context. Discourse Studies 14(6), 731-752.

Marklund, Fredrik \& Nilsson, Anna. 2008. Polisens utredningar av våld mot kvinnor i nära relationer [Police investigations of domestic violence]. Stockholm: Brottsförebyggande

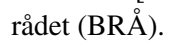

Nacey, Susan. 2012. Scare quotes in L2 English and British English. Language and Computers 74, 117-130.

Pappinen, Anna. 2010. Återberättade berättelser - Om anföringsbruk i förhörstext [Retold stories: Reported speech in police interview texts]. Växjö: Linnaeus University.

Parks, Susan. 2001. Moving from school to the workplace: Disciplinary innovation, border crossings, and the reshaping of a written genre. Applied Linguistics 22, 405-438.

Riktlinjer för skrivande inom Polisen [Guidelines for writing within the police]. 2013. Stockholm: Rikspolisstyrelsen.

Rock, Frances. 2013. Every link in the chain: The police interview as textual intersection. In Chris Heffer, Frances Rock \& John Conley (eds.), Legal-lay communication: Textual travels in the law, 78-103. Oxford: Oxford University Press. 
Rock, Frances. 2017. Recruiting frontstage entextualization: Drafting, artifactuality and written-ness as resources in police-witness interviews. Text \& Talk 37(4), 437-460.

Russell, David. 1997. Rethinking genre in school and society. Written Communication 4, 504-554.

Schneider, Barbara \& Jo-Anne Andre. 2005. University preparation for workplace writing: An explanatory study of the perceptions of students in three disciplines. Journal of Business Communication 2, 195-218.

Smolej, Mirka. 2010. Constructing ideal victims? Violence narratives in Finnish crime-appeal programming. Crime, Media, Culture 6(1), 69-85.

Sperry, Kathryn \& Jason Siegel. 2013. Victim responsibility, credibility, and verdict in a simulated rape case: Application of Weiner's attribution model. Legal and Criminological Psychology 18(1), 16-29.

Trinch, Shonna. 2007. Deconstructing the "stakes" in high stakes gatekeeping interviews: Battered women and narration. Journal of Pragmatics 39(11), 1895-1918.

Voss, James \& Julie van Dyke. 2001. Narrative structure, information certainty, emotional content, and gender as factors in a pseudo jury decision-making task. Discourse Processes 32(2-3), 215-243.

Wergens, Anna. 2002. Ett viktimologiskt forskningsprogram presenterat 2002: Bakgrund och nuläge [A victimologist research programme presented 2002: Background and current state]. Umeå: Brottsoffermyndigheten.

Widlund, Ulf. 2013. Skillnad att spotta mot eller på en polis [The difference between spitting at or on a police officer]. Juridik idag. http://www.nj.se/juridikidag/start (accessed 10 September 2015). 